\title{
Data Acquisition Technologies for Assessing Thermal Comfort in the Built Environment
}

\author{
Merve Kuru, Gulben Calis* \\ Ege University, Department of Civil Engineering, 35040 Bornova, Izmir, Turkey
}

Received: 14 January 2020

Accepted: 10 May 2020

\begin{abstract}
Nowadays, many buildings are equipped with sensors that acquire large amounts of data, which can be useful to monitor, to understand and to identify thermal comfort conditions in buildings. The studies on thermal comfort of building interior spaces are not only numerical analysis based on program outcomes, but also experimental studies to confirm the results of the analysis. However, the most important factor in achieving the correct result in experimental analysis is to plan the data, to select the technology and to determine the test procedure. This study aims at providing an important source for experimental researchers working on thermal comfort by identifying data acquisition technologies that are utilized for capturing thermal comfort related data. Within this context, the study presents existing instruments utilized for monitoring thermal comfort conditions and provides a guideline with respect to technical properties, deployment strategies and time intervals. The findings of this study will be beneficial to practitioners and researchers for selecting and utilizing the most appropriate data acquisition technology for assessing thermal comfort in indoor environments.
\end{abstract}

Keywords: thermal comfort, data acquisition, deployment strategy, time interval, indoor environment

\section{Introduction}

Thermal comfort generally means that the majority of people in an indoor environment are in a certain comfort that maintains both their physical and mental activities in terms of indoor air temperature, relative humidity, air speed as well as other related parameters [1]. Thermal comfort in buildings is important since feeling comfortable in indoor environment directly impacts occupants' mood [2]. Eliminating potential health hazards is also a very important aspect of maintaining ideal thermal comfort. Moreover, thermal

*e-mail: gulben.calis@ege.edu.tr comfort in office buildings contributes not only to wellbeing but also to productivity by enabling occupants to think and work better [3-5]. In addition, it is stated that thermal comfort in educational buildings affects students' attention, perception and learning levels [6,7].

The Predicted Mean Vote (PMV) and Predicted Percentage Dissatisfied (PPD) indices developed by Fanger [8], are calculated to estimate whether a closed environment is perceived as thermally comfortable by a large group of people. Fanger method is adapted by the most commonly used thermal comfort standards, which are the ISO 7730 [9] - "Ergonomics of the thermal environment- Analytical determination and interpretation of thermal comfort using calculation of the PMV and PPD indices and local thermal comfort criteria" used in European countries and the ASHRAE 
Standard 55 [10] - "Thermal Environmental Conditions for Human Occupancy" standards used in the US.

Although the standards recommend operation strategies for buildings, occupants might have diverse thermal comfort requirements in different types of building. Accordingly, several researchers focused on identifying thermal comfort perception and preferences of occupants in various buildings including office buildings, educational buildings, residential buildings, shopping centers, hospitals, historical buildings, mosques and churches. López-Pérez et al. [11] conducted a thermal comfort study in an educational building in a hot-humid climate. The results show that occupants in educational buildings prefer higher comfort temperatures up to $1.0^{\circ} \mathrm{C}$ in reference to current standards. El-Darwish and El-Gendy [12] evaluated occupants' thermal comfort in higher educational buildings located in a hot arid climate. The study findings endorse that the operation of indoor environments should provide favorable conditions which are actually perceived by occupants and are truly responsive to their needs. Maykot et al. [13] investigated the thermal comfort states of women and men in two office buildings which are operated under different airconditioning systems. The results show that females are thermally comfortable in lower temperatures than males in fully air conditioned building whereas males are thermally comfortable in lower temperatures than females in the mixed mode building. Moreover, Rupp and Ghissi [14] compared thermal comfort responses of office workers in both fully air-conditioned and mixed-mode buildings against both the analytical and adaptive models of thermal comfort in the ASHRAE 55 Standard. The results show that the analytical model overestimated the cold sensation of occupants, mainly for natural ventilation mode. Moreover, the application of the adaptive model is determined to be inappropriate for fully air-conditioned buildings.

$\mathrm{Yu}$ et al. [15] investigated thermal comfort in residential buildings on the Tibetan Plateu, China which is located in cold and severe cold zones according to the Chinese climatic division. The results show that the acceptable thermal comfortable zone for the indoor environment of residential buildings in Tibet is within the temperature range between $10.18^{\circ} \mathrm{C}$ and $22.91^{\circ} \mathrm{C}$ under a low relative humidity of $30 \%$. Galassi and Madlener [16] investigated the preferences for practices implemented to adjust thermal comfort in residential buildings. The results reveal a mix of behaviors affecting thermal comfort, some of which may offset energy savings (e.g. tilting the window) while others have more benign effects (e.g. wearing lighter clothes). Kamar et al. [17] developed a simple strategy for improving thermal comfort inside a mosque building in Malaysia. The authors suggested installing exhaust fans which have a potential of reducing the percentage of dissatisfied people by $87-91 \%$. MartinezMolina et al. [18] assessed visitors' thermal comfort in historic museum buildings. The results show that the PMV model predicts the visitors' thermal comfort to be cooler than actual.

Prior research has proven the requirement for monitoring indoor environmental conditions for enhanced thermal comfort conditions for occupants. Currently, the studies on thermal comfort of building interior spaces are not only numerical analysis based on program outcomes, but also experimental studies to confirm the results of the analysis. However, the most important factor in achieving the correct result in experimental analysis is to plan the data, to select the technology and to determine the test procedure. In this context, this study fills an important gap and provides an important source for experimental researchers working on thermal comfort.

This study identifies data acquisition technologies for capturing thermal comfort related data and presents the technologies that are utilized in the academic accomplishments of this domain. The literature is reviewed based on criteria including technical properties, deployment strategies and time interval for monitoring. The following section introduces data requirements for thermal comfort, presents data utilization for thermal comfort and analyzes data acquisition technologies with respect to technical properties, deployment strategies and time interval for monitoring. Then, conclusions are presented.

\section{Data Requirements for Thermal Comfort}

The PMV and PPD indices are suggested by standards $[9,10]$ for determining thermal comfort conditions in indoor environments. PMV is the thermal sensation index that can be used to express the level of thermal comfort in the environment where the heat transfer between the human body and the environment is assumed to be stable. The PMV and PPD indices are calculated by taking into account indoor environmental and personal parameters [19]. The indoor environmental parameters are indoor air temperature, relative humidity, air speed and mean radiant temperature whereas the personal parameters are clothing insulation and metabolic rate.

Indoor air temperature is one of the most important parameters affecting thermal comfort and refers to the dry bulb temperature of the air surrounding the body. It is expressed in degrees Celsius $\left({ }^{\circ} \mathrm{C}\right)$ or Fahrenheit $\left({ }^{\circ} \mathrm{F}\right)$. This parameter affects both sensible and latent heat transfer from both the skin and the respiratory [20]. Accordingly, internal air conditions must be at the recommended values in the standards.

Humidity in the air can be expressed in two ways: absolute and relative humidity. The absolute humidity indicates the amount of water in the air, while the relative humidity indicates the percentage of absolute humidity in the saturated air at the same temperature. Relative humidity in an environment is one of the most important parameters affecting thermal comfort. The recommended relative humidity values in 
air-conditioned buildings are between 30\%-60\% and $40 \%-60 \%$ according to ISO7730 [9] and ASHRAE 55 [10], respectively.

Suitable air speed must be provided to ensure thermal comfort as well as to remove gases and dust that are harmful to health. In free running environments, the internal air speed rate rarely exceeds $0.1 \mathrm{~m} / \mathrm{s}$ [21]. At such low air speed, the movement of the air in the environment decreases and an airless environment is created for the users in the environment [22]. On the other hand, environments with high air speed $(>0.3-0.5 \mathrm{~m} / \mathrm{s})$ cause the occupants to feel the environment cool, breezed and uncomfortable [22]. In addition, the air speed allows heat transfer between the body and the surrounding air. It is known that high air speeds greatly increase heat losses and affect thermal comfort negatively when the body surface temperature is high [23].

The average radiation temperature can be defined as the uniform temperature that should be maintained on the surrounding black surfaces to replace the same amount of heat with the receiving body when the surrounding surfaces are considered [24]. The average radiation temperature at a point in a closed environment varies depending on the proximity of the point to the surfaces that irradiate with high or low intensity, and is influenced by radiation from the environment, users, or equipment [25]. The control of indoor air temperature, relative humidity and air speed, especially in environments exposed to high solar radiation, will not be sufficient to provide thermal comfort for the users due to the effects of the high average radiation temperature [20]. Hot or cold walls and surfaces in the environment will make users feel colder or hotter [20]. Therefore, the average radiation temperature is a factor that must be taken into account to ensure thermal comfort.

The garment clothing and physical characteristics of the occupants affect the thermal resistance used in the calculation of both heat loss and sensible heat loss and the evaporation resistance used in the calculation of latent heat loss [20]. Therefore, the thermal resistance of the garment significantly affects the thermal comfort perception of the occupants. Heat insulation provided by clothing is expressed in clo and 1 clo corresponds to $0.155 \mathrm{Km} 2 / \mathrm{W}$. In general, the heat resistance of the garment in summer light clothing is between about 0.5 and 0.6 clo; in winter clothing ranges from 1 to 1.3 clo $[10,26]$. Insulation values of various garments are included in the standards $[9,10]$.

The metabolic rate is the rate of transformation of chemical energy into heat and mechanical function by metabolic activities in an organism and is generally expressed by the unit area of the total body surface [10]. It is expressed in terms of met / units and 1 met corresponds to $58.2 \mathrm{~W} / \mathrm{m}^{2}[9,10]$. The heat transfer surface area (Dubois surface area) of an average adult person is about $1.8 \mathrm{~m}^{2}$ and produces about $106 \mathrm{~W}$ of energy. For this reason, $106 \mathrm{~W}$ of energy must be disposed as heat loss to the environment in order to make the person feel comfortable. While the heat thrown into the environment in sleep is the minimum, the amount of heat increases as the activity level increases [27]. The details of the metabolic rate and calculation are included in the ISO 8996 standard [28]. Met values corresponding to activities that are often performed by occupants are included in the ISO 7730 [9] and ASHRAE55 [10] standards. In addition, met values corresponding to activities are also found in various sources [3, 26, 29].

\section{Data Acquisition Technologies for Thermal Comfort}

Ambient sensors are widely used to gather data about indoor environmental conditions. In particular, indoor air temperature is measured by temperature sensors [11, $30-34]$ and relative humidity is measured by humidity sensors [11, 30-34]. In addition, data loggers are used for monitoring several parameters (e.g. temperature, relative humidity, light intensity etc.) depending on their self-contained sensors. In literature, data loggers and temperature/humidity meters are commonly used to monitor indoor temperature and relative humidity [6, $15,43-48,35-42]$.

Globe temperature is usually measured by $150 \mathrm{~mm}$. diameter black globe thermometer $[15,31,33,38-40$, 44-47]. It can be also measured by sensors [11,32,49], heat stress meter $[30,43,48,50]$ and data loggers $[36$, 37, 41, 42]. Moreover, external sensors can be used for measuring globe temperature [35]. These sensors are placed inside the hollow copper sphere of $150 \mathrm{~mm}$ diameter coated with matt black paint connected to the external part of data loggers.

Mean radiant temperature values are approximated from the globe and indoor air temperature by using the formula which is recommended by ASHRAE 55 [37, 39, $50-52]$

$$
t_{r}=\left[\left(t_{g}+273\right)^{4}+\frac{1.10 \times 10^{8} V_{a}^{0.6}}{\varepsilon D^{0.4}}\left(t_{g}-t_{a}\right)\right]^{1 / 4}-273
$$

...where $t_{r}$ is the mean radiant temperature $\left({ }^{\circ} \mathrm{C}\right), t_{g}$ is the globe temperature $\left({ }^{\circ} \mathrm{C}\right), V_{a}$ is the air velocity $(\mathrm{m} / \mathrm{s}), t_{a}$ is the air temperature $\left({ }^{\circ} \mathrm{C}\right), \mathrm{D}$ is the globe diameter $(\mathrm{m})$ and $\varepsilon$ is the emissivity.

Air speed is usually measured by 3 different types of instruments: (i) air speed probes that are connected to anemometers [6,11,46-49,53-55,15,30-33,38,44,45]; (ii) ventilation meters $[35,37,50]$ and (iii) data loggers $[36,40,42]$.

Furthermore, there are several instruments such as microclimate stations $[13,41,56]$ and PMV meters [51] that are capable of measuring all of the indoor environmental parameters related to thermal comfort.

ISO 7726 [57] and ASHRAE 55 [10] Standards state the accuracy requirements for indoor environmental measuring instruments (Table 1). 
Table 1. Accuracy requirements for instruments.

\begin{tabular}{|c|c|}
\hline Parameter & $\begin{array}{c}\text { Accuracy requirements in ISO } \\
7726 \text { and ASHRAE55 }\end{array}$ \\
\hline Indoor air temperature & $\begin{array}{c}\text { Maximum: } \pm 0.5^{\circ} \mathrm{C} \\
\text { Ideal: } \pm 0.2^{\circ} \mathrm{C}\end{array}$ \\
\hline Relative humidity & $\pm 5 \% \mathrm{RH}$ \\
\hline Globe temperature & Maximum: $\pm 2^{\circ} \mathrm{C}$ \\
Ideal: $\pm 0.2^{\circ} \mathrm{C}$
\end{tabular}

It can be seen that instruments have to comply with the technical requirements that are indicated by the standards. In order to provide a guideline for selecting the appropriate instrument, Table 2 presents the literature that utilized instruments for monitoring indoor environmental conditions. The results of the review show that almost all of the instruments are compliant with the standards except for the EXTECH HT30 Heat Stress Meter [48, 50], which does not meet the accuracy requirements of indoor air temperature monitoring.

\section{Deployment Strategies for Data Acquisition}

Data acquisition instruments for indoor environmental conditions should be placed close to the center of the monitored space and away from external heat sources, such as laptops, televisions, and monitors, as well as solar radiation $[13,31,35,40,41,49,51$, $55,56]$. In addition, the location of instruments from occupants has to be considered during monitoring. Brager and Dear [58] state that instruments have to be located within $0.5 \mathrm{~m}$ from each occupant horizontally according to the Class II field investigation standard for instrumentation and procedures [50] whereas LópezPérez et al. [11] indicates that the instruments have to run at $10-20 \mathrm{~cm}$ away from the occupants during measurements. On the other hand, several researchers suggest placing the instruments on users' desks or as close to them as possible [34, 36, 47].

The area that could be covered by the instruments should also be taken into account during monitoring. It is indicated that indoor environmental data need to be collected at one central point if the indoor area is less than $16 \mathrm{~m}^{2}[44,46]$. If the indoor area is between $16 \mathrm{~m}^{2}$ and $30 \mathrm{~m}^{2}$, data need to be measured at two points whereas if the indoor area is between $30 \mathrm{~m}^{2}$ and $60 \mathrm{~m}^{2}$, data need to be measured at three points $[44,46]$.

The height of the measurement points is another important part of measuring surveys. There are different standards that recommend the height of the measurement point. In most of the studies conducted in indoor areas where occupants are generally seated (i.e. educational buildings, offices), the measurements are taken in accordance with ISO 7726, at a height

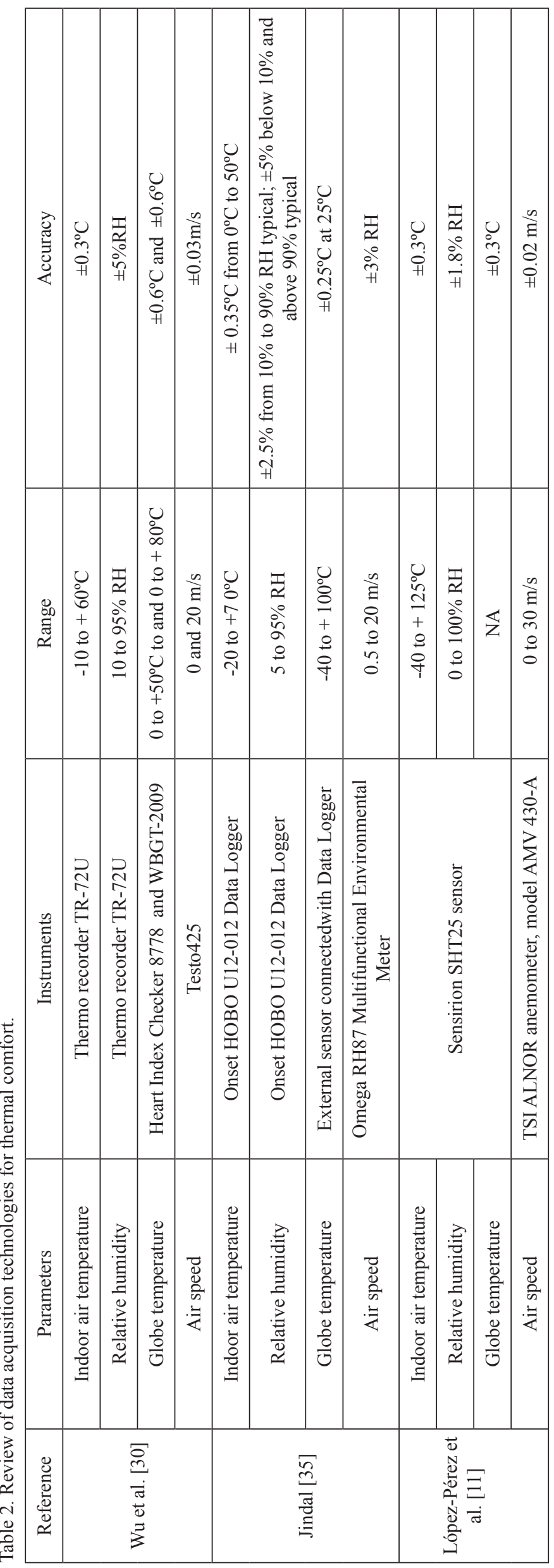




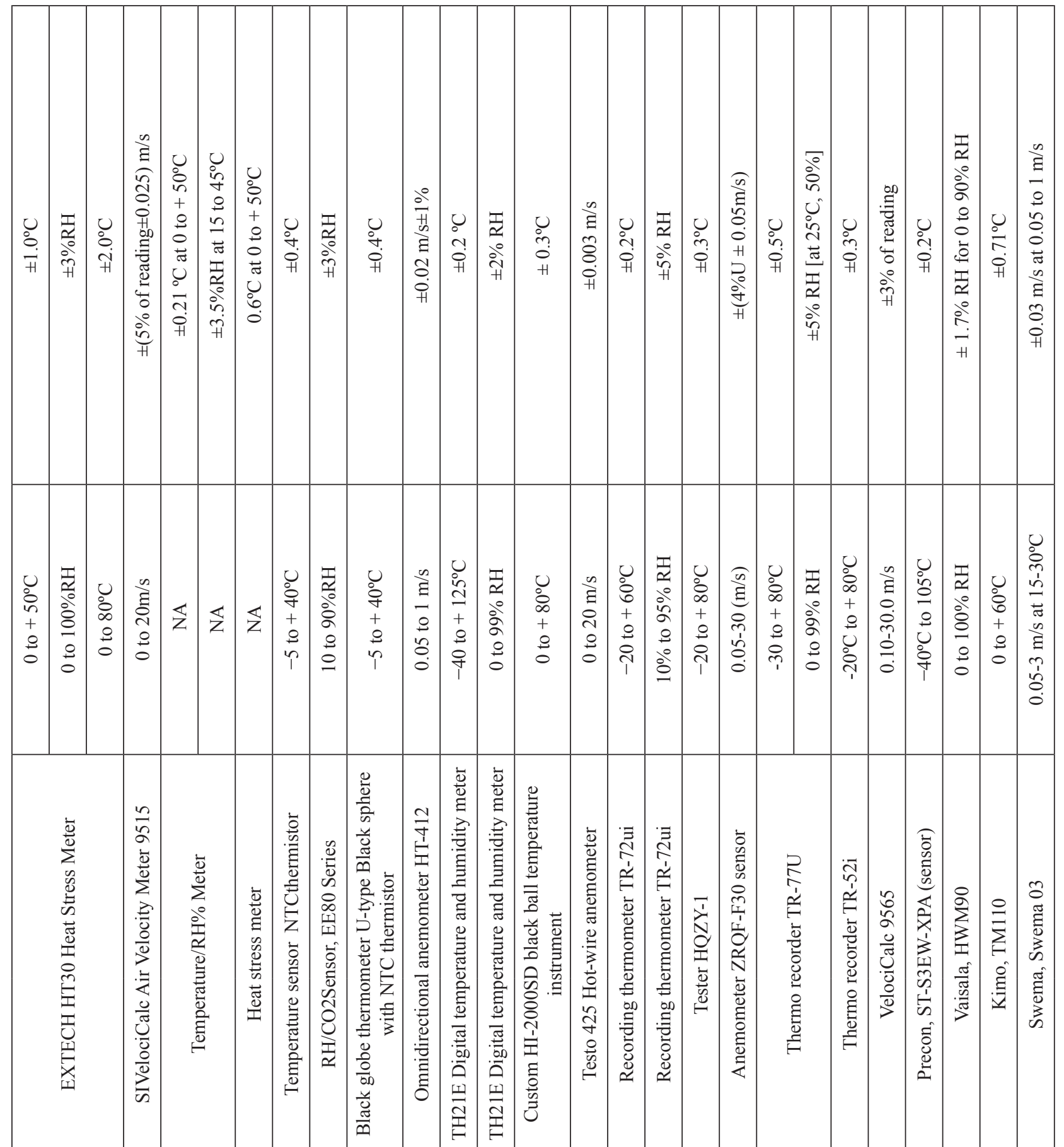

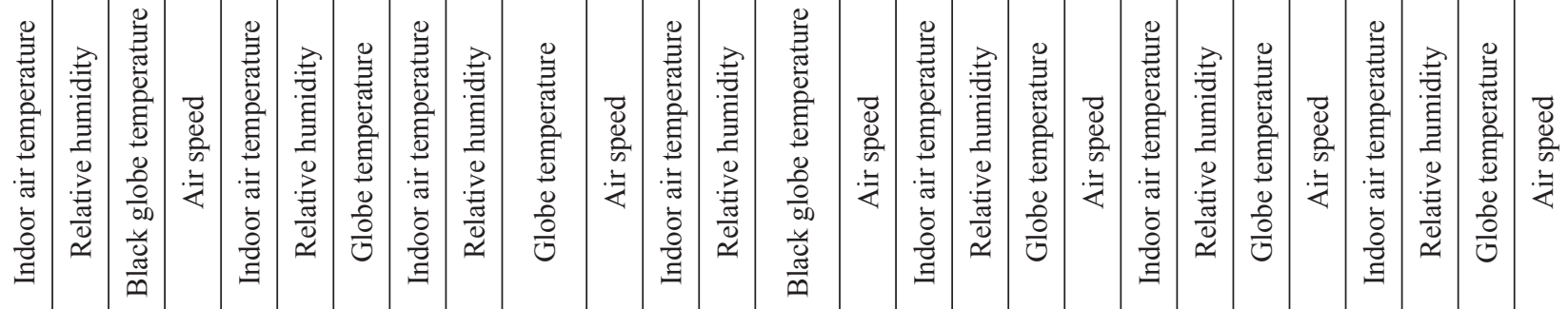

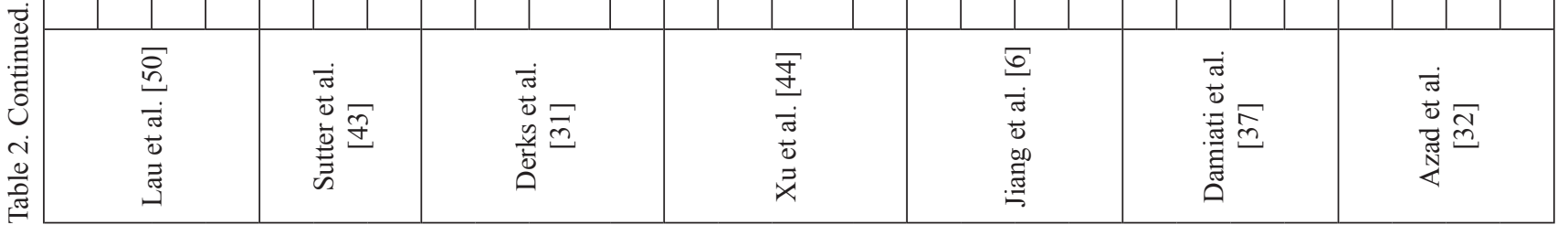




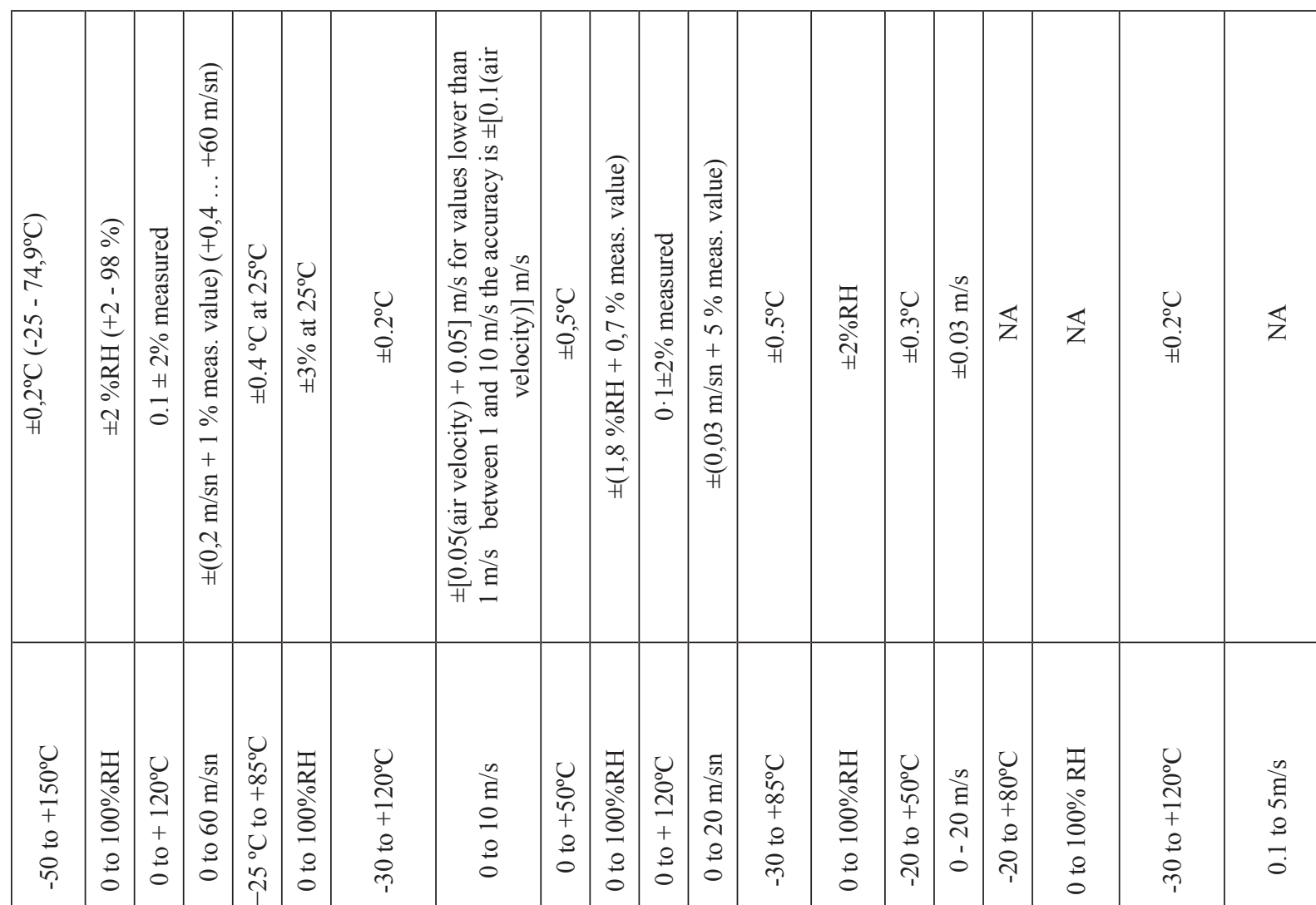

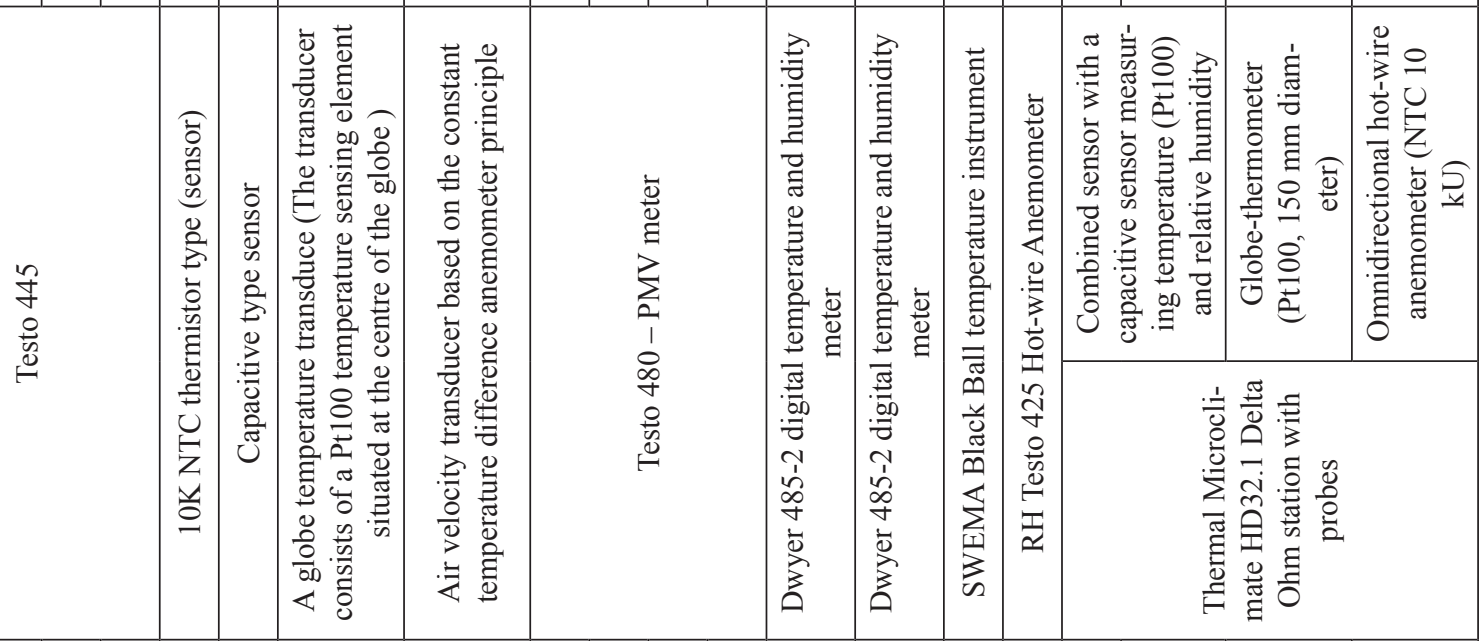

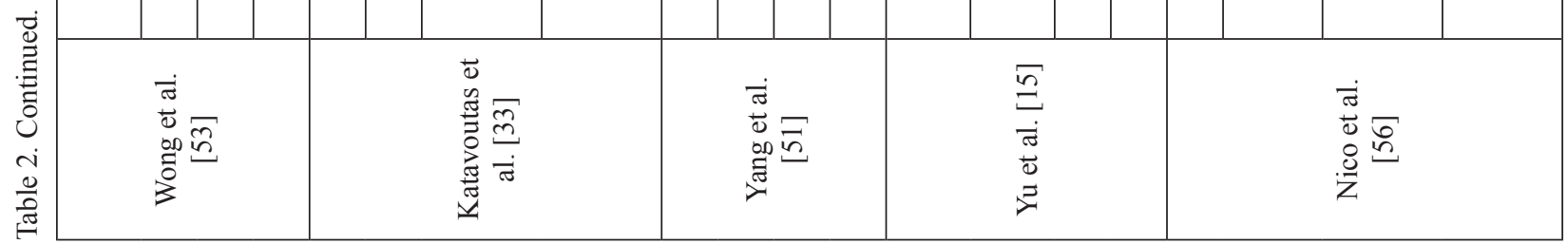




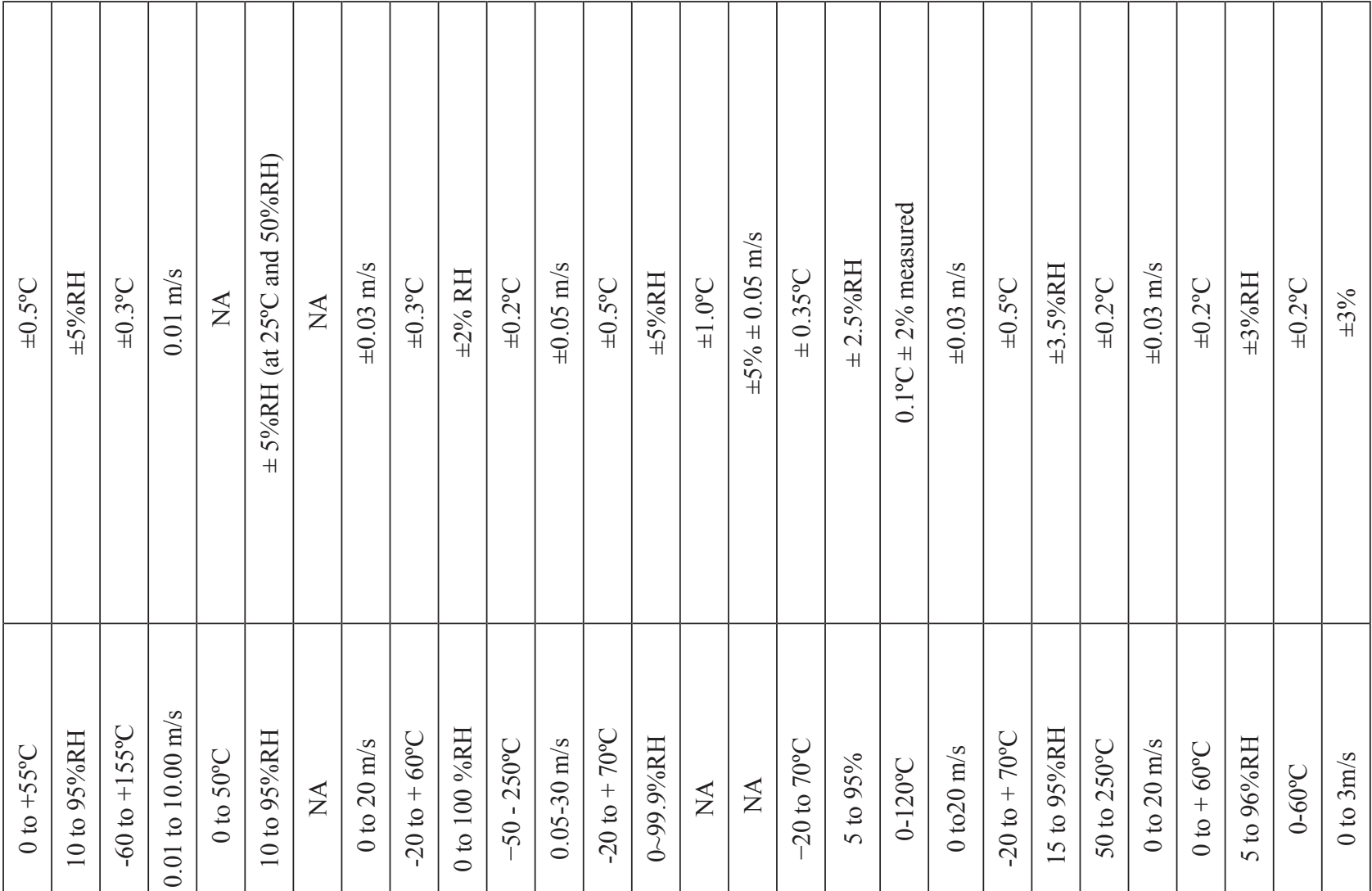

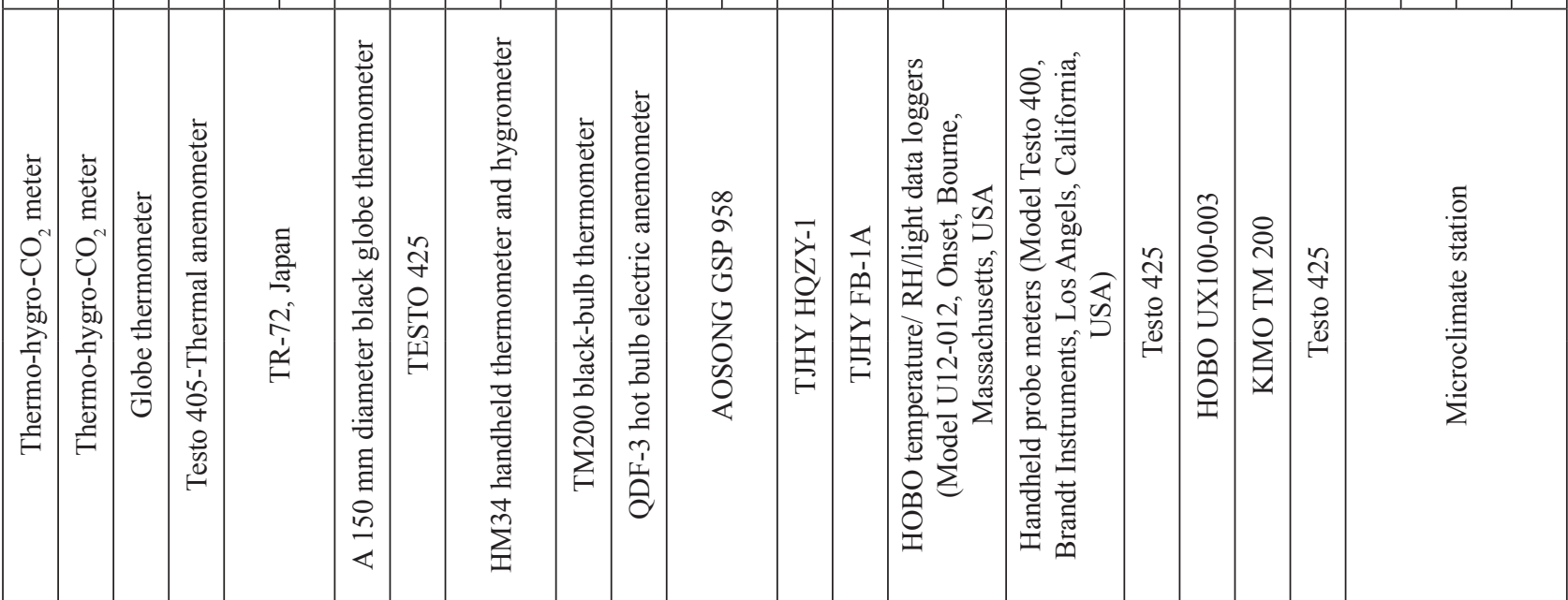

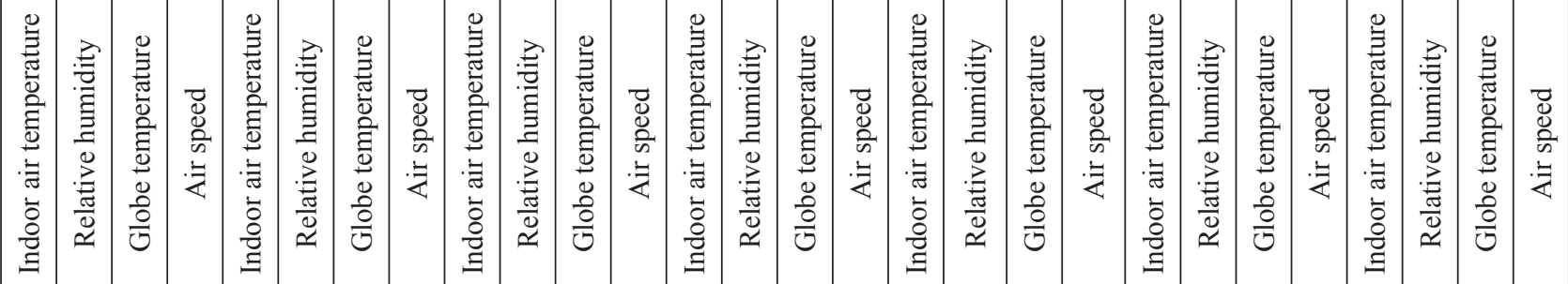

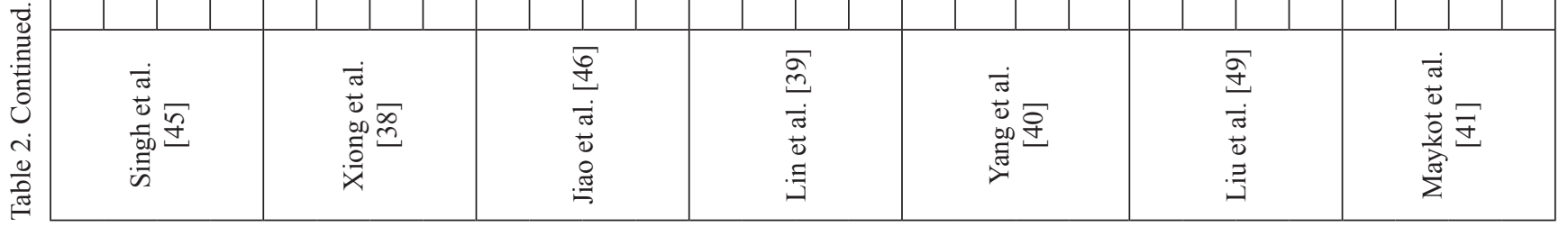




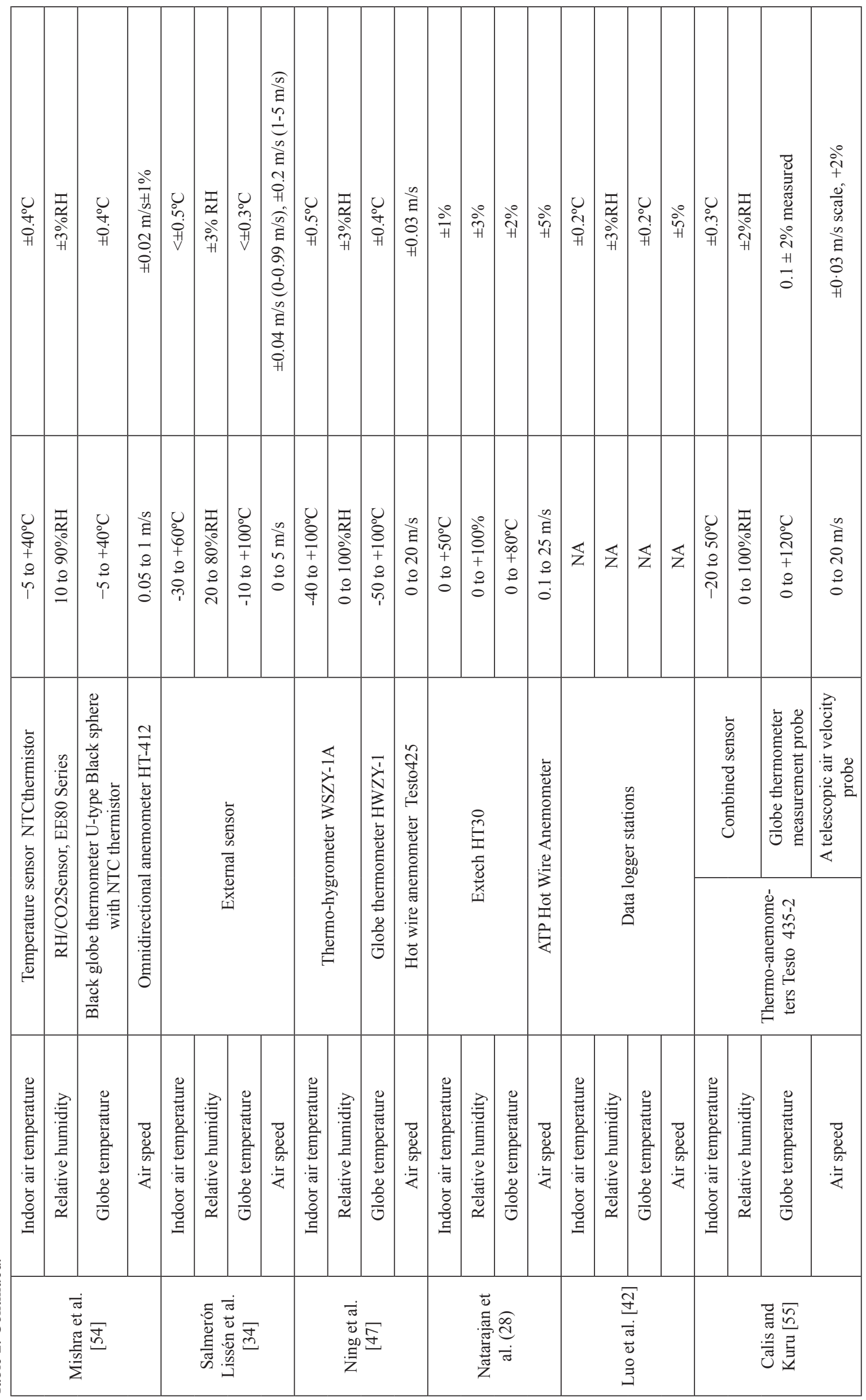


of $1.1 \mathrm{~m}$, which approximately corresponds to a standing person's center of gravity $[15,31-33,35,37,39,40,50$, 56]. There are several studies in which the measuring instruments were set on a tripod $60 \mathrm{~cm}$ above the floor which corresponds to the abdomen height for seated occupants and is recommended by ISO 7726 [13, 41, $49,51]$. On the other hand, Singh et al. [45] took all measurements at neck height of the sitting occupants since the height of occupants as well as the height of their chair considerably varied in the environment. In a specific case presented by Natarajan et al. [48], all the measurements were made at $0.90 \mathrm{~m}$ from floor level since this height is recommended by ASHRAE 55 [10] in relation to placing the probes above desktop level when strong radiant sources (i.e. PCs) are blocked by furniture.

According to ISO 7243 [59], the measurement at the height of the head is at $1.1 \mathrm{~m}$ if sitting and $1.7 \mathrm{~m}$ if standing; at the height of waist at $0.6 \mathrm{~m}$ if sitting, at $1.1 \mathrm{~m}$ if standing; and at the height of ankle at $0.1 \mathrm{~m}$ [11]. In [30] and [43] measurements were taken at 0.1, 0.6 and $1.1 \mathrm{~m}$ height from the ground level.

\section{Time Interval for Data Acquisition}

In literature, there is no consensus on the time interval of measurements. Most of the studies are conducted with 1 min intervals [6, 32, 41, 43, 50, 51, 54]. Moreover, 2 min. interval [56], 5 min interval [40, 49] as well as 15 min interval $[35,36,42]$ are also preferred in the studies. Time intervals can be as frequent as $10 \mathrm{~s}[33,37]$.

\section{Conclusions}

Thermal comfort is essential for maintaining satisfactory conditions for occupants. Accordingly, indoor environmental conditions have to be monitored to ensure that the conditions meet the requirements of occupants. The studies on thermal comfort of building interior spaces are not only numerical analysis based on program outcomes, but also experimental studies to confirm the results of analysis. However, the most important factor in achieving the correct result in experimental analysis is to plan the data, to select the technology and to determine the test procedure. This study aims at providing an important source for experimental researchers working on thermal comfort by identifying data acquisition technologies that are utilized for capturing thermal comfort related data. The results show that the instruments need to meet the accuracy and range requirements of standards in order to be utilized for monitoring thermal comfort conditions. Deployment strategy of instruments has to be determined according to the monitoring duration and the position of people occupying the space. Time interval of monitoring can vary between 10 to 15 mins. The findings of this study will be beneficial to practitioners and researchers for selecting the most appropriate data acquisition technology to capture thermal comfort conditions in buildings. Future studies can focus on providing information about standardization for utilizing these technologies.

\section{Acknowledgements}

This work has received funding from HIT2GAP "Highly Innovative building control Tools Tackling the energy performance gap" project of the European Union's Horizon 2020 research and innovation programme under grant agreement number No. 680708.

\section{Conflict of Interest}

The authors declare no conflict of interest.

\section{References}

1. CALIS G., KURU M. Assessing user thermal sensation in the Aegean region against standards. Sustain Cities Soc., 29, 77, 2017.

2. GENG Y., JI W., LIN B., ZHU Y. The impact of thermal environment on occupant IEQ perception and productivity. Build Environ., 121, 158, 2017.

3. SRINAVIN K., MOHAMED S. Thermal environment and construction workers' productivity: Some evidence from Thailand. Build Environ., 38, 339, 2003.

4. SEVIM D., KURUOĞLU M. Verimliliklerin Mevsime Göre Değişiminin Analizi. E-Journal New World Sci Acad., 7, 544, 2012.

5. YI W., CHAN A.P.C. Effects of heat stress on construction labor productivity in Hong Kong: A case study of rebar workers. Int J Environ Res Public Health, 14, 2017.

6. JIANG J., WANG D., LIU Y., XU Y., LIU J. A study on pupils' learning performance and thermal comfort of primary schools in China. Build Environ., 134, 102, 2018.

7. SINGH M.K., OOKA R., KUMAR A., RIJAL H.B., KUMAR S. Mahapatra S. Progress in thermal comfort studies in classrooms over last 50 years and way forward. Energy Build., 188-189, 149, 2019.

8. FANGER P.O. Thermal Comfort. Malabar, FL, USA: Robert E. Kriege Publishing Company; 1982.

9. ISO 7730, Ergonomics of the Thermal EnvironmentAssessment of the Influence of the Thermal Environment Using Subjective Judgment Scales. Switzerland: International Standardisation Organisation; 2005.

10. ANSI/ASHRAE Standard 55-2017: Thermal Environmental Conditions for Human Occupancy. Atlanta, GA, USA: ASHRAE; 2017.

11. LÓPEZ-PÉREZ L.A., FLORES-PRIETO J.J., RÍOSROJAS C. Adaptive thermal comfort model for educational buildings in a hot-humid climate. Build Environ., 150, 181, 2019.

12. EL-DARWISH I.I., EL-GENDY R.A. Post occupancy evaluation of thermal comfort in higher educational buildings in a hot arid climate. Alexandria Eng J., 57, 3167, 2018. 
13. MAYKOT J.K., RUPP R.F., GHISI E. A field study about gender and thermal comfort temperatures in office buildings. Energy Build., 178, 254, 2018.

14. FORGIARINI RUPP R., GHISI E. Predicting thermal comfort in office buildings in a Brazilian temperate and humid climate. Energy Build., 144, 152, 2017.

15. YU W., LI B., YAO R., WANG D., LI K. A study of thermal comfort in residential buildings on the Tibetan Plateau, China. Build Environ., 119, 71, 2017.

16. GALASSI V., MADLENER R. Shall I open the window? Policy implications of thermal-comfort adjustment practices in residential buildings. Energy Policy, 119, 518, 2018.

17. MOHAMED KAMAR H., KAMSAH N.B., GHALEB F.A., Idrus Alhamid M. Enhancement of thermal comfort in a large space building. Alexandria Eng J., 2018.

18. MARTINEZ-MOLINA A., BOARIN P., TORT-AUSINA I., VIVANCOS J.L. Assessing visitors' thermal comfort in historic museum buildings: Results from a Post-Occupancy Evaluation on a case study. Build Environ., 132, 291, 2018.

19. FANGER P.O. Thermal comfort. Analysis and applications in environmental engineering. Copenhagen: Danish Technical Press.; 1970.

20. ATMACA İ., YIĞIT A. Evaluation of Thermal Comfort for Air-Conditioned Environments with Transient Regime Energy Balance Model, Journal of Plant Engineering, 99, 61, 2005.

21. HÖPPE P., MARTINAC I. Indoor climate and air quality. Review of current and future topics in the field of ISB study group 10. Int J Biometeorol, 42, 1, 1998.

22. YÜKSEL N. Study Directed at Determining Structural Comfort Conditions for Present Public Institutions, Uludağ University Journal of The Faculty of Engineering, 10, 21, 2005.

23. YIĞIT A., HORUZ İ. The effect of air speed and movement on thermal comfort conditions, $10^{\text {th }}$ Thermal Science and Technology National Conference, Ankara, Turkey, 603, 1995.

24. BARKER A.H. Proceedings Instituion Heating Ventilation Engineers. London: 1932.

25. TREDRE B.E. Assessment of Mean Radiant Temperature in Indoor Environments. Occup Environ Med., 22, 58, 2008.

26. HAVENITH G., HOLMÉR I., PARSONS K. Personal factors in thermal comfort assessment: Clothing properties and metabolic heat production. Energy Build., 34, 581, 2002.

27. YAŞAR Y., PEHLEVAN A., ALTINTAŞ E. . An Investigation of Thermal Comfort Conditions in Primary School Classrooms, VIII Plant Engineering National Conference, 199, 2007.

28. ISO 8996, Ergonomics of the thermal environment - Determination of metabolic rate. International Standardisation Organisation; 2004.

29. MCQUISTON F.C., PARKER J.D. Heating, Ventilating, And Air Conditioning Analysis And Design. New York: John Wiley \& Sons; 1994.

30. LI J., WARGOCKI P., LI N., CUI H., WU Z., PENG J. Adaptive thermal comfort in naturally ventilated dormitory buildings in Changsha, China. Energy Build., 186, 56, 2019.

31. DERKS M.T.H., MISHRA A.K., LOOMANS M.G.L.C., KORT H.S.M. Understanding thermal comfort perception of nurses in a hospital ward work environment. Build Environ., 140, 119, 2018.

32. AZAD A.S., RAKSHIT D., WAN M.P., BABU S., SARVAIYA J.N., KUMAR DEVSK, et al. Evaluation of thermal comfort criteria of an active chilled beam system in tropical climate: A comparative study. Build Environ., 145, 196, 2018.

33. KATAVOUTAS G., ASSIMAKOPOULOS M.N., ASIMAKOPOULOS D.N. On the determination of the thermal comfort conditions of a metropolitan city underground railway. Sci Total Environ., 566-567, 877, 2016.

34. SALMERÓN LISSÉN J.M., BARBADILLA-MARTÍN E., BROTAS L., GUADIX MARTÍN J., APARICIO-RUIZ P. Field study on adaptive thermal comfort in mixed mode office buildings in southwestern area of Spain. Build Environ., 123, 163, 2017.

35. JINDAL A. Thermal comfort study in naturally ventilated school classrooms in composite climate of India. Build Environ., 142, 34, 2018.

36. BARBADILLA-MARTÍN E., GUADIX MARTÍN J., SALMERÓN LISSÉN J.M., SÁNCHEZ RAMOS J., ÁLVAREZ DOMÍNGUEZ S. Assessment of thermal comfort and energy savings in a field study on adaptive comfort with application for mixed mode offices. Energy Build., 167, 281, 2018.

37. DAMIATI S.A., ZAKI S.A., ABD RAZAK A,. RIJAL H.B., HAGISHIMA A. Adaptive thermal comfort in university classrooms in Malaysia and Japan. Build Environ., 122, 294, 2017.

38. XIONG J., LIAN Z., ZHOU X., YOU J., LIN Y. Effects of temperature steps on human health and thermal comfort. Build Environ., 94, 144, 2015.

39. LIN B., WANG Z., SUN H., ZHU Y., OUYANG Q. Evaluation and comparison of thermal comfort of convective and radiant heating terminals in office buildings. Build Environ., 106, 91, 2016.

40. YANG B., OLOFSSON T., WANG F., LU W. Thermal comfort in primary school classrooms: A case study under subarctic climate area of Sweden. Build Environ., 135, 237, 2018.

41. MAYKOT J.K., RUPP R.F., GHISI E. Assessment of gender on requirements for thermal comfort in office buildings located in the Brazilian humid subtropical climate. Energy Build., 158, 1170, 2018.

42. LUO M., CAO B., DAMIENS J., LIN B., ZHU Y. Evaluating thermal comfort in mixed-mode buildings: A field study in a subtropical climate. Build Environ., 88, 46, 2015.

43. SUTTER M., OLIVER T., LAWRENCE T.M., DOUGLASS S.P., SHARPTON T.N., AGHNIAEY S. Thermal comfort evaluation in campus classrooms during room temperature adjustment corresponding to demand response. Build Environ., 148, 488, 2018.

44. XU C., LI S., ZHANG X., SHAO S. Thermal comfort and thermal adaptive behaviours in traditional dwellings: A case study in Nanjing, China. Build Environ., 142, 153, 2018.

45. SINGH M.K., OOKA R., RIJAL H.B., TAKASU M. Adaptive thermal comfort in the offices of North-East India in autumn season. Build Environ., 124, 14, 2017.

46. JIAO Y., YU H., WANG T., AN Y., YU Y. Thermal comfort and adaptation of the elderly in free-running environments in Shanghai, China. Build Environ., 118, 259,2017 
47. NING H., WANG Z., ZHANG X., JI Y. Adaptive thermal comfort in university dormitories in the severe cold area of China. Build Environ., 99, 161, 2016.

48. NATARAJAN S., RODRIGUEZ J., VELLEI M. A field study of indoor thermal comfort in the subtropical highland climate of Bogota, Colombia. J Build Eng., 4, 237, 2015.

49. LIU G., CEN C., ZHANG Q., LIU K., DANG R. Field study on thermal comfort of passenger at high-speed railway station in transition season. Build Environ., 108, 220, 2016.

50. LAU S.S.Y., ZHANG J., TAO Y. A comparative study of thermal comfort in learning spaces using three different ventilation strategies on a tropical university campus. Build Environ., 148, 579, 2019.

51. YANG J., NAM I., SOHN J.R. The influence of seasonal characteristics in elderly thermal comfort in Korea. Energy Build., 128, 583, 2016.

52. SALATA F., GOLASI I., CIANCIO V., ROSSO F. Dressed for the season: Clothing and outdoor thermal comfort in the Mediterranean population. Build Environ., 146, 50, 2018.

53. WONG N.H., TAN E., GABRIELA O., JUSUF S.K. Indoor Thermal Comfort Assessment of Industrial Buildings in Singapore. Procedia Eng., 169, 158, 2016.
54. MISHRA A.K., DERKS M.T.H., KOOI L., LOOMANS M.G.L.C., KORT H.S.M. Analysing thermal comfort perception of students through the class hour, during heating season, in a university classroom. Build Environ., 125, 464, 2017.

55. CALIS G., KURU M. Statistical significance of gender and age on thermal comfort: a case study in Turkey. Proc Inst Civ Eng Eng Sustain., 172, 40, 2019.

56. NICO M.A., LIUZZI S., STEFANIZZI P. Evaluation of thermal comfort in university classrooms through objective approach and subjective preference analysis. Appl Ergon., 48, 111, 2015.

57. ISO 7726, Ergonomics of the thermal environment e instruments for measuringphysical quantities. Geneva: International Standardisation Organisation; 2001.

58. GAIL B., DEAR R.J.D.E. Thermal adaptation in the built environment: a literature review. Energy Build., 27, 83, 1998.

59. ISO 7243, Ergonomics of the thermal environment Assessment of heat stress using the WBGT (wet bulb globe temperature) index. International Standardisation Organisation; 2017. 